\title{
Utworzenie Kasy Oszczędności w Wolnym Mieście Krakowie i jej działalność w latach 1844-1857
}

Instytucja Kasy Oszczędności, utworzonej w Wolnym Mieście Krakowie w lipcu 1844 r., nie była dotąd obiektem zainteresowania historyków skarbowości. Za podstawę źródłową niniejszego opracowania służyły przede wszystkim materiały archiwalne przechowywane w Archiwum Narodowym w Krakowie; w pierwszej kolejności tzw. akta senackie (sygn. WMK V-102 B), stanowiące spuściznę aktową po Senacie Rządzącym, sprawującym w Rzeczypospolitej Krakowskiej ,zwierzchnią władzę administracyjną”. Ważnym źródłem były także akta Zgromadzenia Reprezentantów, czyli sejmu Wolnego Miasta Krakowa, który uchwalił ustawę konstytuującą Kasę Oszczędności. Cenne uzupełnienie stanowiły „Dzienniki Praw” i „Dzienniki Rządowe”, a także krakowska prasa. Korzystałem także z opracowań dotyczących dziejów Krakowa w pierwszej połowie XIX stulecia. Spośród nich szczególnie użyteczne jest dzieło Juliana Miłkowskiego, napisane głównie w oparciu o akta Rady Miasta Krakowa. Wymienione materiały pozwoliły na dość precyzyjne odtworzenie ram organizacyjnych Kasy Oszczędności, a także jej sytuacji finansowej i roli w życiu mieszkańców Krakowa i okręgu krakowskiego w połowie XIX w. ${ }^{1}$

Komunalne kasy oszczędności, do których zaliczała się również krakowska Kasa Oszczędności, mają na ziemiach polskich długą tradycję. W polskim systemie kredytowym pojawiły się one przed około dwustu laty, od początku

1 J. Miłkowski, Kilka słów o Kassie Oszczędności i Banku ubogich, Kraków 1852. Należy zaznaczyć, że po znacznej części dokumentacji związanej z Kasą Oszczędności zachował się jedynie wykaz akt. Zob. Konsygnacja akt dotyczących się Statutu i Funduszów Kassy Oszczędności w Mieście Krakowie zorganizowanej, Archiwum Narodowe w Krakowie (dalej: ANK), zespół „Archiwum WMK” (dalej: WMK), sygn. V-102 B, k. 1229-1230. Wybrakowanie akt nastąpiło 22 XII 1859. 
spełniając doniosłą rolę. Różniły się przy tym od innych instytucji bankowych, zwłaszcza jeśli chodzi o zakres zadań. W ich działalności najważniejsze były operacje bierne, czyli gromadzenie oszczędności, jak też dbałość o zapewnienie odpowiedniego oprocentowania od złożonych kapitałów. Dlatego przy większych wkładach kasy udzielały kredytów na stosunkowo niewielkie kwoty. Działały przeważnie na rynku lokalnym, udzielając kredytu osobom, które miałyby trudności z otrzymaniem kredytu w banku. Dzięki gwarancjom państwowym bądź samorządowym kasy oszczędności cieszyły się dużym zaufaniem lokalnych społeczności. Na ziemiach polskich po raz pierwszy pojawiły się zaborze pruskim; palmę pierwszeństwa dzierżyła kasa poznańska, działająca w latach 1827-1833 i ponownie od $1838 \mathrm{r}$. W świetle pruskiego regulaminu z 1838 r. kasy oszczędności nie miały osobowości prawnej; były przedsiębiorstwami zakładanymi i kierowanymi przez związki samorządowe (miasta, powiaty), które udzielały gwarancji za ich zobowiązania „całym swym majątkiem i siłą podatkową". Kasy dawały sposobność do lokowania drobnych oszczędności, przy czym znaczną część środków umieszczały w kilkuletnich pożyczkach hipotecznych, wiejskich i miejskich. W zaborze rosyjskim kasy oszczędności można było tworzyć w miastach gubernialnych, od $1841 \mathrm{r}$. Pierwsze tego rodzaju placówki powstały w 1843 r. w Warszawie i Płocku².

W Galicji działalność kas oszczędności regulowało rozporządzenie z 2 września 1844 r., przyznające im osobowość prawną ${ }^{3}$. Kasy miały się opierać na ofiarności społecznej, a nie na powiązaniach z konkretnym związkiem komunalnym, chociaż zezwolono na tworzenie kas gminnych i powiatowych. Właściwe związki komunalne miały ręczyć za wkłady i ich należyte oprocentowanie, całym swoim majątkiem oraz ,siłą podatkową". Zalecano przy tym jak najniższe określanie wysokości wkładów, aby z dobrodziejstw oszczędzania mogli korzystać najubożsi. Ustalono też maksymalną wysokość kwot pieniężnych, które można było wpłacać do kas. Przepisy obowiązujące w Galicji dopuszczały lokowanie pieniędzy w pożyczkach hipotecznych z „,zabezpieczeniem pupilarnym”, pożyczkach na papiery

${ }^{2}$ W. Morawski, Stownik historyczny bankowości polskiej do 1939 roku, Warszawa 1998, s. 55; H. Nowak, Bankowość w Polsce, t. I, Warszawa 1932, s. 131; K. Windakiewicz, Komunalne Kasy Oszczędności w Rzeczypospolitej Polskiej (Organizacja dotychczasowa, ustrój i ustawodawstwo obecne), Poznań 1928, s. 6-7.

${ }^{3}$ Kasy oszczędności w monarchii habsburskiej tworzono na podstawie najwyższej uchwały cesarza Ferdynanda I z 2 IX 1844 r. Połączona Kancelaria Nadworna wydała w tej sprawie dekret z 26 IX 1844 r. W Galicji zasady dotyczące działalności kas oszczędności podano w obwieszczeniu Gubernium z 31 X 1844 r. G. Zamoyski, Prawne podstawy funkcjonowania komunalnych kas oszczędności na ziemiach polskich w okresie zaborów, „Czasopismo Prawno-Historyczne”, t. LIII, 2001, z. 1, s. 216; Tekst w J. Piwocki (red.), Zbiór ustaw i rozporządzeń administracyjnych, t. IV, Lwów 1903, s. 90. 
państwowe, pożyczkach dla zakładów zastawniczych i instytucji ogólnej użyteczności, papierach wartościowych, zaliczkach dla gmin oraz przez dyskonto weksli. W 1844 r. powstała we Lwowie Galicyjska Kasa Oszczędności ${ }^{4}$.

Podobne instytucje funkcjonowały z powodzeniem również w krajach Europy Zachodniej. Miłkowski podawał przykład Francji, w której pierwszą kasę utworzono w $1818 \mathrm{r}$. W przeciągu ćwierć wieku odnotowała ona 66-krotny wzrost kapitałów, z 6 mln franków w 1818 r. do 397 mln franków w 1845 r. Rząd francuski podjął zresztą działania mające na celu ograniczenie zbytniego rozwoju tej instytucji, wprowadzając ograniczenia w wysokości składek. Również w Wielkiej Brytanii dość popularne było odkładanie pieniędzy na stały fundusz (kilkaset tysięcy funtów szterlingów rocznie); zakłady tego rodzaju działały też w Belgii, Holandii oraz państewkach włoskich i niemieckich ${ }^{5}$.

Propozycja utworzenia kasy oszczędności w Krakowie po raz pierwszy pojawiła się na forum Zgromadzenia Reprezentantów, w połowie grudnia 1817 r. Projekt przedstawił poseł ks. Mateusz Dubiecki (gmina VI miejska); pragnął on, aby głównymi beneficjariuszami kasy zostali urzędnicy, których nie obejmował jeszcze wówczas żaden państwowy system emerytalny, gwarantujący wypłatę zaopatrzenia po odejściu ze służby rządowej ${ }^{6}$.

Marszałek sejmu Feliks Radwański skierował projekt Dubieckiego do przeanalizowania Wydziałowi Spraw Wewnętrznych. Jednakże pojawienie się na forum parlamentu projektu rozwiązującego problem urzędniczych emerytur autorstwa Józefa Sołtykowicza - spowodowało, że koncepcja utworzenia kasy oszczędności nie została urzeczywistniona ${ }^{7}$. Jedynym pokrewnym tematem, jaki pojawił się w dyskusji publicznej była propozycja utworzenia Banku Krajowego. Jak zauważył jednak obserwator wydarzeń, choć podstawowym celem projektowanego banku również miało być ożywienie gospodarcze, intensyfikacja ruchu pieniężnego oraz zwiększenie liczby operacji finansowych, to jednak opierał się

${ }^{4}$ W. Morawski, op. cit., s. 56; K. Windakiewicz, op. cit., s. 8-10; G. Zamoyski, op. cit. s. 216217; B. Petz, Komunalne Kasy Oszczędności w Polsce do 1939 r., „Kancelaria Sejmu. Biuro Studiów i Ekspertyz. Wydział Analiz Budżetowych", Informacja nr 129, kwiecień 1993, s. 1-2. Szerzej zob. Z. Witaszczyk, Kasy oszczędności w Galicji na tle kas oszczędności w monarchii habsburskiej, „Prace Historyczno-Archiwalne”, t. V, Rzeszów 1997, s. 153-186.

5 J. Miłkowski, op.cit., s. 3-5. Poparcie dla idei oszczędzania dostrzegał Miłkowski również w pracach Jeana Baptista Saya (np. w „Traite, d'économie politique”).

${ }^{6}$ Urzędnicy w Wolnym Mieście Krakowie mogli liczyć jedynie na doraźne wsparcie, odwołując się do Zgromadzenia Reprezentantów bądź Senatu Rządzącego. Ustawę emerytalną uchwalono w 1833 r. Szerzej zob. M. Mataniak, System emerytalny dla urzędników Wolnego Miasta Krakowa. Część I: lata 1815-1837, „Krakowskie Studia z Historii Państwa i Prawa”, t. 10, 2017, z. 2, s. 289-318.

7 Wystąpienie Dubieckiego miało miejsce na posiedzeniu 9 (13 XII 1817). Zob. „Gazeta Krakowska” nr 102 z 21 grudnia 1817 roku. Projektu nie przesłano więc Senatowi, który był organem mającym prawo występowania z inicjatywą ustawodawczą do Zgromadzenia Reprezentantów. 
on na zasadniczo odmiennych założeniach prawno-organizacyjnych, w porównaniu z Kasą Oszczędności

Sprawa Kasy Oszczędności musiała czekać na swoją kolej ponad ćwierć wieku9 . Dopiero w początkach 1844 r. krakowskie Arcybractwo (Archikonfraternia) Miłosierdzia i Banku Pobożnego - najstarsza w Polsce, zasłużona katolicka organizacja dobroczynna - wystąpiła z inicjatywą ustanowienia Kasy Oszczędności w Krakowie ${ }^{10}$. Wniosek w imieniu towarzystwa przedłożył Piotr Bartynowski, jeden ze starszych Arcybractwa ${ }^{11}$. Jego argumentacja pełna była odniesień do wartości chrześcijańskich, zwłaszcza obowiązku niesienia pomocy ubogim, co określił jako zachowanie „szlachetne i miłości chrześcijańskiej odpowiednie”. Zwracał uwagę na „pomnażającą się liczbę ubogich wyciągających rękę po wsparcie”, których tragicznej sytuacji nie były w stanie polepszyć zakłady (towarzystwa) dobroczynne, obecne w Krakowie „w liczbie większej niż w niejednej stolicy znakomitych państw”. Dalece niewystarczająca był też „troskliwa opieka Rządu, usiłującego środkami, jakie są w Jego mocy, pomnożyć dobry byt i usuwać przyczyny do ubóstwa prowadzące". Również środki Archikonfraterni, mimo ofiarności dużej grupy darczyńców, były nieadekwatne do potrzeb. Wyjściem z sytuacji było powołanie Kasy Oszczędności. Była ona instytucją dobrze znaną w cywilizowanych krajach Europy Zachodniej (,ledwie nie w każdym większym mieście istniejących"). Jak przekonywał Bartynowski, w tamtejszych warunkach „kasy takie w krótkim czasie zbawienne wywarły skutki”. Twierdził, że przyczyną nędzy jest najczęściej niedostatek gotówki, a także „brak uwagi, aby zbywający grosz od koniecznych potrzeb zachować na nieprzewidziane wypadki”. Bartynowski dostrzegał wielorakie korzyści płynące z oszczędzania, zwłaszcza możliwość „wcześniejszego ratowania się od niedostatku”. W Rzeczypospolitej Krakowskiej służba domowa czy rzemieślnicy nierzadko wydawali sporą część

8 J. Miłkowski, op.cit., s. 5-6.

9 Warto odnotować, że 1843 r. projekt organizacji Kasy Oszczędności przesłał Senatowi urzędnik Urzędu Pocztowego w Berlinie, F. Mannling, ale jego propozycja została odłożona ad acta. J. Miłkowski, op.cit., s. 7.

${ }^{10}$ Arcybractwo założono w 1584 r. z inicjatywy Piotra Skargi. Jego siedziba mieściła się w kamienicy nr 53 przy ul. Siennej. W I poł. XIX w. dysponowało ono majątkiem sięgającym ok. $1 \mathrm{mln}$ złp (250 000 złr). Dochody z kapitałów ulokowanych z zabezpieczeniem hipotecznym na dobrach w Królestwie Polskim i w Okręgu Krakowskim oraz na kamienicach w Krakowie, przynosiły corocznie ok. 40000 złp. Kwotę przeznaczano na jałmużny, wypłatę posagów, szpitale, utrzymanie podrzutków, wsparcie dla młodzieży rzemieślniczej, nabożeństwa i działalność tzw. Banku Pobożnego. Więcej zob. J. Demel, Stosunki gospodarcze i społeczne Krakowa w latach 1846-1853, „Biblioteka Krakowska" nr 107, Kraków 1951, s. 106-107 oraz Sprawozdanie z czynności Rady Administracyjnej za rok 1850, (do nr 273), ANK, „Papiery Piotra Michałowskiego”, sygn. 29/645/171, k. 121-122.

${ }^{11}$ Pismo Archikonfraterni Miłosierdzia i Banku Pobożnego do Senatu Rządz. z 5 I 1844, WMK V-102 B, k. 1339-1340 i 1377. P. Bartynowski był sędzią Trybunału I Instancji oraz sędzią Sądu Apelacyjnego. 
zarobku „na pijaństwo, granie w loterię liczbową i inne złe nałogi”. Złudne było przeświadczenie przedstawicieli tych warstw społecznych, że „chwilowe powodzenie w zarobkach niezmiennem będzie”. Kasa Oszczędności miała stanowić zachętę dla ludności do gromadzenia i pomnażania swoich oszczędności. Pomóc w tym miało naliczanie ,procentów od procentów”, tworzących „małe kapitały, tyleż przy rozpoczęciu jakiego zawodu, związkach małżeńskich, w podupadłym stanie, chorobie lub wieku podeszłym pomocne". W imieniu Arcybractwa Bartynowski zaofiarował kwotę 6000 złp. Miała ona stanowić „fundusz żelazny”, będący gwarancją wypłacalności Kasy; miał on umożliwić każdorazową wypłatę sum pieniężnych, na żądanie oszczędzających, po lokowaniu wniesionych kapitałów. Autor memoriału zastrzegł zwrot powyższej sumy w sytuacji, gdy Kasa Oszczędności zgromadzi odpowiednie fundusze, w rezultacie zainwestowania wpłaconych pieniędzy (,z oszczędzonych procentów zebrane") $)^{12}$.

Opinię w sprawie sporządził jeden z referentów Wydziału Spraw Wewnętrznych. Uznał on wniosek za uzasadniony, oparty na bezsprzecznych faktach (,dowodzić takowej byłoby rzeczą zbyteczną"). Wkrótce urzędnicy wydziału opracowali projekt ustawy, w którym uwzględniono niektóre rozwiązania organizacyjne kas oszczędności w Berlinie, Wrocławiu i Magdeburgu, jak też w Królestwie Polskim. Punktem stycznym były na przykład postanowienia art. 34, dotyczące tzw. kwoty nienaruszalnej, która miała być dostępna na żądanie oszczędzających ${ }^{13}$. Należy zaznaczyć, że zgodę na utworzenie Kasy Oszczędności wyraziła Konferencja Rezydentów, nadzorująca życie społeczno-polityczne z ramienia „mocarstw opiekuńczych" (Austria, Rosja i Prusy). Senat przedstawił jej sytuację coraz liczniejszej grupy ludzi niezamożnych, zreferował trudności z udzielaniem im wsparcia, zwrócił też uwagę na dotkliwy brak zakładu dobroczynnego, który zajmowałby się nie udzielaniem jałmużny, lecz zachęcaniem obywateli do oszczędzania $^{14}$. Rezydenci wyrazili zgodę na utworzenie Kasy Oszczędności, o czym powiadomiono pełnomocnika wnioskodawcy ${ }^{15}$.

12 Pismo Archikonfraterni Miłosierdzia i Banku Pobożnego do Senatu Rządz. z 5 I 1844, WMK V-102 B, k. 1339-1340 i 1377.

13 Pismo Wydziału Spraw Wewnętrznych do Senatu Rządz. z 25 I 1844 nr 1249 (do nr 183 DGS), WMK V-102 B, k. 1339-1340 i 1377. Rozwiązaniem analogicznym do obowiązujących w Królestwie Polskim było też domniemanie, że posiadacz książeczki oszczędnościowej jest uważany za właściciela zapisanych na niej środków. W ogólności, referent uznał wniesienie projektu pod obrady Zgromadzenia Reprezentantów za całkowicie uzasadnione.

${ }_{14}$ Pismo Senatu Rządz. do Konferencji Rezydentów z 12 II 1844 nr 804, WMK V-102 B, k. 1337-1338, 1379. Senat poinformował o kwocie 6000 złp zaoferowanej na uruchomienie Kasy Oszczędności, oparciu się na rozwiązaniach pruskich i królewsko-polskich. Przesłanie projektu (z annexami) nastąpiło na podstawie art. 27 Statutu Urządzającego Zgromadzenia Polityczne $\mathrm{z} 1833 \mathrm{r}$.

15 Pismo Senatu Rządz. do Archikonfraterni Miłosierdzia i Banku Pobożnego z 12 II 1844 nr 804 (do nr 183), WMK V-102 B, k. 1335-1336, 1381. 
Niebawem Zgromadzenie Reprezentantów rozpoczęło prace nad zgłoszonym projektem. Z kronikarskiego obowiązku można odtworzyć skład sejmu 1844 r., w którego bogatym dorobku wyróżniała się ustawa konstytuująca Kasę Oszczędności. Jako przedstawiciele Senatu zasiedli w nim Jacek Księżarski i Wiktor Kopff, delegatami Krakowskiej Kapituły Katedralnej byli ks. Franciszek Stachowski i ks. Karol Teliga; Uniwersytet Jagielloński wydelegował profesorów: Ferdynanda Kojsiewicza oraz Fryderyka Hechla; jako przedstawiciele gmin miejskich zasiedli w parlamencie Marcin Soczyński, Jan Hieronim Rzesiński, Franciszek Hahn, Józef Kremer (syn), Hilary Meciszewski, Stanisław Ciechanowski, Jan Librowski, Konstanty Benoe; z ramienia gmin okręgowych Ludwik Straszewski, Michał Okoński, Walenty Janutka, Jan Żebrowski, Paweł Ślizowski, Stanisław Zamojski, Jan Kalisiewicz, Józef Strauss, Kazimierz Jadowski, Franciszek Łącki, Antoni Lipczyński, Mikołaj Szauer ${ }^{16}$. Marszałkiem sejmu wybrano Księżarskiego, który na asesorów sejmowych wyznaczył Benoego i Łąckiego ${ }^{17}$. W dalszej kolejności obsadzono dwie komisje sejmowe, prawodawczą i skarbową ${ }^{18}$. O wniesieniu projektu urządzenia Kasy Oszczędności prezes Senatu poinformował posłów w uroczystym akcie zwołania sejmu ${ }^{19}$. Wiadomość o tym znalazła się także w programie prac sejmowych ${ }^{20}$.

Zgodnie z obowiązującą procedurą zgłoszony przez Senat projekt stał się przedmiotem debaty poselskiej. Tekst ze zmianami odesłano rządowi, który po ustosunkowaniu się do nich przesłał projekt do prac w komisjach sejmowych. Po zapoznaniu się z uwagami komisji, Senat „wystąpił z inicjatywą” do Zgromadzenia Reprezentantów ${ }^{21}$. O przyjęciu ustawy rząd został powiadomiony przez sejm,

${ }^{16}$ Lista Reprezentantów na Zgromadzenie w roku 1844, „Akta Seymowe z roku 1844”, ANK, WMK II-44, k. 29. W sejmie ponadto zasiedli sędziowie pokoju Juliusz Florkiewicz, Kajetan Kowalski, Antoni Rozwadowski, Aleksander Estreicher.

17 „Diariusz Seymowy r. 1844”, ANK, WMK II-43, k. 2-3. Odbyło się to 3 VI 1844. Sekretarzem sejmowym mianowano F. Kojsiewicza.

18 „Diariusz Seymowy r. 1844”, WMK II-43, k. 5-7. W komisji sejmowo-skarbowej zasiedli H. Meciszewski, F. Łącki, L. Straszewski, K. Benoe i F. Kojsiewicz, w sejmowo-prawodawczej M. Soczyński, J.H. Rzesiński, J. Kremer, K. Kowalski i F. Hechel. Prezes Senatu (Jan Schindler) wyznaczył do komisji L. Sobolewskiego oraz W. Szpora. Pismo Prezesa Senatu Rządz. do Prezydującego w Zgromadzeniu Reprezentantów z 4 VI 1844 nr 2565 DGS, WMK II-44, k. 155.

${ }_{19}$ Akt Zwolujacy Zgromadzenie Reprezentantów z 20 V 1844 nr 2337 DGS, WMK II-44, k. 27.

${ }^{20}$ Pismo Senatu Rządz. do Prezydującego w Zgromadzeniu Reprezentantów z 4 VI 1844 nr 2565 DGS, WMK II-44, k. 155-159. Projekt miano rozpatrzyć zgodnie z kolejnością inicjatyw prawodawczych wniesionych przez Senat.

${ }^{21}$ Pismo Senatu Rządz. do Prezydującego w Zgromadzeniu Reprezentantów z 28 VI 1844 nr 3012, WMK V-102 B, k. 1291. Wniesienie zmodyfikowanego projektu nastąpiło na podstawie art. 15 i 159 Statutu Urządzającego Zgromadzenia Polityczne. 
który nakazał jej publikację w,Dzienniku Praw”22. Należy odnotować, że głównymi orędownikami Kasy Oszczędności byli posłowie Straszewski, Meciszewski i Librowski ${ }^{23}$.

Analiza postanowień ustawy z 3 lipca 1844 r. przekonuje, że oferta Kasy Oszczędności była skierowana do najuboższych (w każdym razie: niezamożnych) mieszkańców Krakowa. Wyraźnie wynika to z art. 1 głoszącego, że kasa ma „uboższym wszelkiego stanu mieszkańcom dopomóc w bezpiecznym a korzystnym umieszczeniu pomniejszych kwot pracą i oszczędnością zebranych". Autorzy ustawy wyrazili przekonanie, że nawet nieduże sumy pieniężne mogą stanowić istotną pomoc ,przy rozpoczęciu jakiego zawodu, związkach małżeńskich, w podupadłym stanie, chorobie lub wieku podeszłym". Wpłacone do kasy kwoty miały być oprocentowane. Zarząd złożonymi środkami finansowymi powierzono Dyrekcji Kasy Oszczędności w Krakowie. Należy dodać, że ustawodawca miał w planach utworzenie podobnych kas oszczędności w miasteczkach okręgowych: Trzebini, Jaworznie, Chrzanowie i Nowej Górze. Ostatecznie powstała jedynie filia Kasy w Jaworznie ${ }^{24}$.

Na czele Dyrekcji Kasy Oszczędności postawiono jednego z senatorów. W jej skład mieli ponadto wchodzić delegat Arcybractwa Miłosierdzia, wskazany na dwuletnią kadencję, czterej obywatele Rzeczypospolitej Krakowskiej, wyznaczeni przez Senat - również na dwa lata oraz szef Biura Rachuby. Ustawa wprowadzała obowiązkowy nadzór Senatu nad Dyrekcją Kasy. Wśród jej obowiązków znalazło się czuwanie nad przestrzeganiem statutu (regulaminu) Kasy, jak też nad „zarządem kasowym, celowi odpowiadającym”25.

Wyrazem troski władz o bezpieczeństwo powierzonych pieniędzy były przepisy art. 8 ustawy. Nakazano w nim, aby przyjmowanie i wypłata pieniędzy („czynności kassowe”) dokonywały się wyłącznie rękami fachowych, powołanych przez Senat „urzędników kaucjonowanych”, którzy ponosili odpowiedzialność za wyrządzone szkody. Byli nimi urzędnicy rachunkowi: kasjer i buchalter-kontroler. Zgodnie z obowiązującą procedurą, kasjer przyjmował i wypłacał pie-

22 Pismo Prezydującego w Zgromadzeniu Reprezentantów do Senatu Rządz. z 4 VII 1844 (do nr 3107), WMK V-102 B, k. 1255. Ogłoszenie miało nastąpić na podstawie art. 171 Statutu Urządzającego Zgromadzenia Polityczne.

${ }^{23}$ Domagali się oni uprzedniego ogłoszenia projektu drukiem, celem jego popularyzacji wśród mieszkańców. Propozycji sprzeciwił się marszałek Hoszowski który przekonywał, że spowoduje to opóźnienie prac sejmowych. Nie miało przy tym znaczenia, że sejm miał pracować przez blisko 3 tygodnie. Protokół 7 posiedzenia Zgromadzenia Reprezentantów z 24 VI 1844, „Diariusz Seymowy r. 1844", WMK II-43, k. 127-128.

${ }^{24}$ Ustawa z 3 VII 1844, Zaprowadzenie Kass oszczędności, ogłoszona pismem Senatu Rządz. z 5 VII 1844 nr 3107 DGS, „Dziennik Praw Wolnego Miasta Krakowa” z 1844 roku (art. 1-2).

${ }^{25}$ Ibidem (art. 5-6). Dwaj spośród obywateli, wyznaczeni w pierwszej kolejności, mieli pełnić swoje obowiązki przez 4 lata. 
niądze osobiście bądź przy pomocy „dodanego individuum”; cały obrót pieniężny odnotowywał on w „Dzienniku kasowym”, czyli tzw. manuale ${ }^{26}$ oraz w „Książce kwitowej"27.

Dla oszczędzających niebagatelne znaczenie miały rządowe gwarancje każdorazowej wypłaty pieniędzy wraz z należnymi odsetkami (procentami). Rząd ręczył także za „całość i bezpieczeństwo powierzonych funduszów”. Senat miał ustalić godziny otwarcia Kasy w ten sposób, aby z jej usług bez przeszkód mogli korzystać najubożsi, zajęci zarobkowaniem Krakowianie („klasy służących i z dziennego zarobku żyjących" ${ }^{28}$.

W ustawie wprowadzono limity kwot pieniężnych, które można było wpłacać do Kasy Oszczędności. Minimalną ustalono na 1 złp, maksymalną na 20 złp. Zastrzeżono, że w ciągu tygodnia nie można wpłacić więcej niż 50 złp. Ponadto, na koncie jednej osoby (w „książce kwitowej”) nie mogło się znajdować więcej niż 1000 złp wraz z sumą odsetek (procentów). Oprocentowanie wkładów ustalono na $4 \%$, choć pierwotnie zakładano, że będzie wynosić $6 \%$. Obliczano je dopiero po wpłaceniu przynajmniej 5 złp, tak więc oszczędzający zyskiwali 6 gr. na każdych wpłaconych 5 złp. Były to zyski stosunkowo niewielkie, jednakże zgodne z podstawowymi założeniami Kasy Oszczędności ${ }^{29}$.

Procenty obliczano poczynając od pierwszego dnia miesiąca następującego po miesiącu, w którym dokonano pierwszej wpłaty. „Procenty od funduszów” miano doliczać do łącznego kapitału z końcem każdego roku kalendarzowego. Procenty przypadające na dzień 31 grudnia zapisywano na rachunku właściciela pod pozycją przychodów uzyskanych w styczniu, a następnie dodawano do sumy kapitałów. Sumę uzyskanych procentów, po weryfikacji w Kasie Oszczędności, miano wpisywać do „książki kwitowej”. Do wzrostu oszczędności miało się przyczyniać m.in. doliczanie („dorachowywanie”) procentów przypadających od procentów, od 1 stycznia każdego roku poczynając. Przy wypłacie pieniędzy brano pod uwagę wysokość oprocentowania w ostatnim dniu miesiąca poprzedzającego ${ }^{30}$.

26 Zob. Wzór Dziennika czyli Manuału Kassy Oszczędności (do nr 3012 DGS), WMK V-102 B, k. 1321-1323.

${ }^{27}$ Ustawa Zaprowadzenie Kass oszczędności (art. 7-8). Wpłacane pieniądze wciągano do „Księgi kassowej kosztowej”, na podstawie danych z „Książki kwitowej”. Należało to do obowiązków kontrolera Kasy Oszczędności, na zasadach określonych w art. 13-14 ustawy.

${ }^{28}$ Ibidem (art. 3-4). Kasa miała być otwarta „w sposób najdogodniejszy dla składających fundusze”. Godziny pracy miały uwzględniać zarówno ich chęć wnoszenia środków pieniężnych, jak też ich wypowiadania i odbierania.

${ }^{29}$ Dokładniej obrazowała to „Tabela przyrostu kapitału w Kassie Oszczędności złożonego”, stanowiąca załącznik do ustawy z 1844 r. Po miesiącu oszczędzania oszczędzający, który wpłacił 5 złp zarabiał kolejne 6 gr. Po dwóch miesiącach na jego koncie było 5 złp 12 gr., po trzech miesiącach 5 złp 18 gr. itd. W tabeli rozpisano zyski dla osób wpłacających od 5 do 200 złp.

${ }^{30}$ Ibidem (art. 9-11). 
W ustawie dużo miejsca poświęcono prowadzeniu „książek kwitowych”. Zawierały one numer rachunku, który odnotowywano również w księgach kasowych. Książki miały ponumerowane strony (,liczbowane stronice”) oraz nadruk z herbem Wolnego Miasta Krakowa. Każda z nich miała być podpisana przez przewodniczącego i dwóch członków Dyrekcji. Na końcu znajdowała się „tabela przyrostu kapitału", a także informacja o terminach oraz miejscu wpłaty i wypłaty kapitałów; wymagane było podanie dat poszczególnych wpłat wraz z wysokością kwoty; dane osobowe właściciela wpisywano przy pierwszej wpłacie. Analogiczne zasady obowiązywały przy odnotowywaniu wypłaty pieniędzy („,częściowy wydatek funduszów”), wypłata całości oszczędności mogła nastąpić jedynie za zwrotem „książki kwitowej”. Ta ostatnia miała być zgodna z „książką kwitową” prowadzoną przez Kasę Dyrekcji. Dbałość o należyte prowadzenie „książek kwitowych" spoczywała na ich posiadaczach; w razie podejrzenia jej podrobienia bądź wątpliwości co do autentyczności zajmowano zakwestionowany egzemplarz, który przekazywano Dyrekcji Kasy; z czynności sporządzano protokół ${ }^{31}$. „Książki kwitowe” były podstawowym dowodem na wpłacenie pieniędzy do Kasy Oszczędności, jako że wyłącznie jej „ukaziciel” był uważany za jej „,prawego właściciela". Również pieniądze z konta można było podjąć jedynie na jej podstawie ${ }^{32}$.

Ustawa wprowadzała ważny wyjątek, przemawiający na niekorzyść „ukaziciela książki kwitowej”. Było nim wpisanie ostrzeżenia w księgach kasowych przez rzeczywistego właściciela. Wśród obowiązków oszczędzających znalazło się ,staranne chowanie książki, aby ta do rąk niewłaściwych nie przeszła”. Kasa mogła wprawdzie „odroczyć wypłatę”, jednakże tylko wówczas, gdyby „okaziciel książki osobą o jej nieprawe posiadanie okazywał się". Ostateczna decyzja należała do Dyrekcji Kasy. Kolejny artykuł (19) dotyczył postępowania w przypadku zniszczenia lub zagubienia „książki kwitowej”. W pierwszej kolejności należało zgłosić zdarzenie w Kasie Dyrekcji, które następnie odnotowywano w „Księdze kasowej”. Otrzymanie duplikatu następowało na podstawie decyzji Dyrekcji Kasy. Wydanie książeczki bez formalności mogło mieć miejsce w razie udowodnienia, że jej utrata nastąpiła wskutek wypadku. W pozostałych przypadkach, w razie wątpliwości, Dyrekcja zarządzała śledztwo, po czym następowało trzykrotne ogłoszenie w prasie, że miała miejsce utrata książeczki

${ }^{31}$ Ibidem (art. 12-17). Dowodem w postępowaniu wyjaśniającym była bezwzględnie „księga kasowa”; wpisy do „książki kwitowej” dodatkowo podpisywali kasjer i buchalter Kasy Oszczędności.

${ }^{32}$ Każda „książka kwitowa” miała osobny numer, wpisywano w niej dane osobowe właściciela, a także wysokość wpłacanych i wypłacanych kwot pieniężnych (w złp i gr.), z oznaczeniem daty operacji. Przy każdej czynności wymagano podpisu kasjera i buchaltera. Zob. Książka kwitowa Kassy Oszczędności WMK, WMK V-102 B, k. 1355, 1368-1369. 
przez właściciela. Wiązało się z to z jej umorzeniem, o czym także ogłaszano publiczności ${ }^{33}$. Przestrzegania powyższej procedury dowodzi przykład umorzenia książeczki kwitowej nr 580, wystawionej dla górników kopalni węgla „Pechnik” w Jaworznie ${ }^{34}$.

Wypłata („wypowiedzenie”) kwot nie większych niż 100 złp następowała na każdorazowe żądanie (,zaraz za zgłoszeniem się”), kwot wyższych nie później niż po upływie 15 dni od zgłoszenia żądania, ,przez oświadczenie ustne lub na piśmie". Jeżeli oszczędności na jednej książeczce (wraz z odsetkami) osiągnęły kwotę 1000 złp, właściciel miał obowiązek odebrania swoich oszczędności w terminie trzymiesięcznym. Gdyby tego nie uczynił, nieodebrany kapitał był składany w Depozycie Kasy. Oszczędzającemu przysługiwał odtąd jedynie ,procent prosty" (4\%). Spoczywający na Kasie Oszczędności obowiązek naliczania procentów wygasał po upływie trzydziestu lat od ostatniej wpłaty; jeżeli zgłoszenie się po odbiór zdeponowanych pieniędzy nie nastąpiło mimo trzykrotnego ogłoszenia, dochodziło do ich przepadku na rzecz Kasy Oszczędności ${ }^{35}$. Dyrekcja prowadziła także „Księgę kontową”, która zawierała informacje o wysokości wpłat na poszczególne konta, w układzie chronologicznym ${ }^{36}$.

Oszczędności zgromadzone w kasie podręcznej Kasy Oszczędności miały być z końcem miesiąca wpłacane do Kasy Głównej Wolnego Miasta Krakowa i ,zachowywane w osobnej skrzyni”. Zdeponowane fundusze miano inwestować („elokować, wypożyczać”), z odpowiednim zabezpieczeniem hipotecznym („,na pewną hipotekę"), przy oprocentowaniu 5\%, w ratach półrocznych, na zasadach obowiązujących dla tzw. sum pupilarnych. W razie trudności z lokowaniem za oszczędności mogły być nabywane „obligacje procentowe” w szczególności czteroprocentowe listy zastawne, które również podlegały, w miarę możliwości, „wypożyczeniu na pewną hipotekę"; wyżej wskazane czynności wymagały zgody Senatu ${ }^{37}$.

Ustawa przyznawała Senatowi prawo wydania rozporządzenia, które uwzględniając „korzyści dla przemysłu krajowego”, zezwalałoby na wypożyczanie wniesionych do Kasy Oszczędności pieniędzy, „na zastawy ruchome” lub „za

${ }^{33}$ Ustawa Zaprowadzenie Kass oszczędności (art. 18-19). Śledztwo toczyło się na koszt właściciela „książki kwitowej” w sytuacji, gdy na koncie była zgromadzona kwota powyżej 20 złp.

${ }^{34}$ Obwieszczenie Dyrekcji Kasy Oszczędności Krakowskiej z 12 I 1850 nr 13, Dz. Rząd. MK z 23 I 1850 nr 15, s. 60. Po trzykrotnym ogłoszeniu i wskutek braku osób zgłaszających się, nastąpiło jej umorzenie oraz wydanie duplikatu stronie zainteresowanej.

${ }^{35}$ Ustawa Zaprowadzenie Kass oszczędności (art. 20-21).

36 Wzór Księgi kontowej Kassy Oszczędności (do nr 3012 DGS), WMK V-102 B, k. 1317-1319. Odnotowywano też wypłaty z poszczególnych kont. Do księgi dołączono tabelkę, która pozwalała zorientować się, jak szybko rosną oszczędności na koncie, w kolejnych miesiącach (,rozrachowanie stopy procentowej").

${ }^{37}$ Ustawa Zaprowadzenie Kass oszczędności (art. 22). 
zaręczeniem odpowiedzialnych osób", z rękojmią bezpieczeństwa i przy oprocentowaniu $6 \%{ }^{38}$.

Można nadmienić, że Kasa Oszczędności świadczyła jeszcze inne usługi finansowe. Można wśród nich wskazać wnoszenie obligacji procentowych, w tym listów zastawnych, o wartości nie większej niż 1000 złp, jako „depozyt prosty”, za pokwitowaniem kwitami sznurowymi. Zastrzeżono że wszelkie fundusze w gotówce („,gotowiźnie”) bądź w „,papierach rządowych”, które przeniesiono z Kasy Oszczędności do Kasy Głównej WMK będą traktowane jak depozyt; ich wypłata mogła mieć miejsce wyłącznie na podstawie upoważnienia („za asygnacją”) Senatu, na wniosek Dyrekcji Kasy Oszczędności. W kasie podręcznej miała się zawsze znajdować kwota pozwalająca na zwrot pieniędzy, na żądanie oszczędzających. Kluczami do kasy podręcznej dysponował kasjer i buchalter Kasy Oszczędności, gromadzący fundusze „na bieżąco”; klucze do Kasy Głównej trzymali kasjer oraz jeden z urzędników Dyrekcji; dwóch członków tej ostatniej miało co miesiąc odbywać kontrole (,rewizje”) stanu kasy (,szluss kasy”), z których sporządzano protokoły rewizyjne ${ }^{39}$.

Ustawa wprowadzała wymóg corocznych rewizji Kasy Głównej Oszczędności przez Dyrekcję, przy udziale pracownika Biura Rachuby. Jej wyniki publikowano w styczniowym numerze „Gazety Krakowskiej”. Sprawozdanie zawierało informacje o stanie Kasy Oszczędności oraz „obraz ruchu wniesionych i wypłaconych oszczędności”. Osobny raport otrzymywał Senat, który mógł zlecić rewizję nadzwyczajną ${ }^{40}$.

Koszty administracji Kasą Oszczędności miano częściowo pokrywać z nadwyżki (,przewyżki”) procentów uzyskanych z pieniędzy wpłacanych do Kasy; w dalszej kolejności zyski miały trafiać na cele dobroczynne, np. zapomogi dla „podupadłych rzemieślników, rękodzielników i służących”, po potrąceniu odpowiedniej sumy na fundusz rezerwowy. Wynagrodzenie urzędników Kasy miano określić w osobnym etacie, proporcjonalnie do nakładu pracy („stopień ich zatrudnien"" ${ }^{41}$.

Wpłata pieniędzy oraz dalsze korzystanie z usług Kasy Oszczędności było nieodpłatne, wyjąwszy opłatę 10 gr. za wydanie „książki kwitowej”. Fundu-

${ }^{38}$ Ibidem (art. 23).

39 Ibidem (art. 24-28). Obligacje procentowe miały „własne zabezpieczenia”, stąd nie wymagały „osobnego zaręczenia” (nie stosowano do nich postanowień art. 3 ustawy); obowiązkowo przechowywano je w tzw. kasie zasobowej Kasy Oszczędności; w początkach działalności kasa podręczna (do momentu „uzbierania odpowiednich funduszów”) otrzymała wsparcie ze Skarbu Publicznego „na pierwszy zakład”.

${ }^{40}$ Ibidem (art. 31-32). Wskazano, że „obraz ruchu funduszów” powinien obejmować „zbiorowo numery”, bez podawania nazwisk korzystających z usług Kasy Oszczędności; powinien za to zawierać informację o „zaszłych szczególnych wypadkach, z Kasą Oszczędności związek mających”.

${ }^{41}$ Ibidem (art. 29-30). 
sze gromadzone w Kasie nie podlegały egzekucji za długi. Podlegały zwrotowi na każde żądanie ${ }^{42}$. Istotnym uzupełnieniem ustawy z $1844 \mathrm{r}$. była opublikowana w formie załącznika „Tabela przyrostu kapitału w Kasie Oszczędności złożonego"43.

Przechodząc do początków działalności Kasy Oszczędności, należy odnotować, że w sierpniu 1844 r. prowizor Drukarni Akademickiej poinformował o wydrukowaniu 2000 egzemplarzy „książeczek kwitowych” (co kosztowało 410 złp. 28 gr.), jak też sporządzeniu dwóch egzemplarzy (rysunków) „Tabeli na Księgę kontową" i „Tabeli na Dziennik”. W związku z tym we wrześniu 1844 r. Wydział Spraw Wewnętrznych zawiadomił Senat o przygotowaniu „niezbędnych do manipulacji druków i ksiąg". W początkowym okresie funkcjonowania Kasy Oszczędności niebagatelną rolę odegrało wsparcie udzielone przez Arcybractwo Miłosierdzia i Banku Pobożnego w Krakowie ${ }^{44}$.

Jesienią 1844 r. Senat podjął dalsze działania, które miały ułatwić Kasie Oszczędności zainicjowanie działalności. Na siedzibę, ze względu na „początkowo szczupłe jej czynności”, wyznaczył lokal zajmowany przez Kasę Główną WMK. Kasa Oszczędności rozpoczęła działalność 6 października 1844 r. Miała być czynna codziennie w godzinach od 10 do 13, również w dni świąteczne, za wyjątkiem „Świąt Wielkich”. Stało się tak przez wzgląd na mieszkańców Krakowa, w dni powszednie zajętych pracą zarobkową ${ }^{45}$. Wkrótce wprowadzono zmianę, polegającą na wydłużeniu czasu jej pracy: w tygodniu miała być czynna od 9 do 14, w niedziele w godzinach od 11:30 do 13. Rząd nakazał Kasie Głównej przyjmowanie i wypłacanie pieniędzy codziennie z wyjątkiem sobót oraz trzech dni przed i po pierwszym dniu każdego miesiąca ${ }^{46}$. Wydział Spraw Wewnętrznych zasugerował też, aby spośród

${ }^{42}$ Ibidem (art. 34-36). Fundusze nie podlegały ,aresztowi ani poszukiwaniu, celem zaspokojenia skarbowych lub prywatnych należytości”. Czynności Kasy Oszczędności („wszelkie działania”) zwolniono od opłat stemplowych (,papieru stemplowego”). Opłatę 10 gr. uiszczano przy zwrocie „książki kwitowej”, aczkolwiek według pierwszego projektu ustawy opłata miała być wnoszona również przy jej odbiorze.

${ }^{43}$ Ustawa z 3 VII 1844 roku, Zaprowadzenie Kass oszczędności, ogłoszona pismem Senatu Rządz. nr 3107 DGS, „Dziennik Praw WMK” z 1844 r., por. wyżej przypis 29.

${ }^{44}$ Pismo Prowizora Drukarni Akademickiej do Wydz. Spraw Wewnętrznych z 28 VIII 1844, WMK V-102 B, k. 1241. Można dodać, że oprawa 2000 egzemplarzy „Książeczek kwitowych” przez introligatora kosztowała 233 złp 10 gr. Niezbędne było też sporządzenie pieczęci z napisem „Kasa Oszczędności WMK”.

${ }^{45}$ Pismo Senatu Rządz. do Wydz. Spraw Wewnętrznych, Kasy Głównej, Biura Rachuby, Archikonfraterni Miłosierdzia, redakcji „Dziennika Rządowego” i „Gazety Krakowskiej” z 20 IX 1844, WMK V-102 B, k. 1231-1233.

46 Obwieszczenie Senatu Rządz. z 18 X 1844 nr 4901, Dz. Rząd. WMK z 26 X 1844 nr 128-129, s. 515. Uznano zarazem, że czas świąteczny powinien być przeznaczony na „dopełnienie obowiązków religijnych". 
2000 egzemplarzy pierwszej partii „książek kwitowych” w Kasie Dyrekcji przechowywać jedynie $500^{47}$.

Pierwszym przewodniczącym (,prezydującym”) Dyrekcji Kasy Oszczędności został Wiktor Kopff, ceniony krakowski prawnik ${ }^{48}$. Jego zastępcą mianowano Konstantego Hoszowskiego, sędziego Sądu Wyższego, a zarazem przedstawiciela Arcybractwa Miłosierdzia ${ }^{49}$. Spośród obywateli Wolnego Miasta Krakowa w zarządzie znaleźli się Leon Bochenek i Jan Wolański (przez 4 lata) oraz Ludwik Helcel i Józef Czech (2 lata). Z urzędu obecny był szef Biura Rachuby Karol Płocki. Funkcje kasjera powierzono urzędnikowi Biura Rachuby Kajetanowi Jędrzejowskiemu (zarazem kontroler Kasy Głównej), buchalterem-kontrolerem mianowano Teodora Witkowskiego (zarazem aplikant-dietariusz Kasy Głównej) ${ }^{50}$. W latach 1846-1847 w Dyrekcji Kasy Oszczędności miały miejsce niewielkie roszady personalne ${ }^{51}$.

W dalszej kolejności zostaną przedstawione dane dotyczące kwot pieniężnych, wpłacanych do Kasy Oszczędności. Informacje takie znajdowały się w obwieszczeniach Dyrekcji Kasy, które publikowano, na podstawie art. 32 ustawy, w dodatku do „Dziennika Rządowego”. W ogólności można stwierdzić, że były one stosunkowo niewielkie. Wpłaty roczne do Kasy nie przekraczały 10 tys. złp. W pierwszym okresie działalności, czyli od 6 października 1844 do 31 grudnia 1846 r. na 264 książeczkach oszczędnościowych w Krakowie ${ }^{52}$ oraz ośmiu

47 Pismo Wydz. Spraw Wewnętrznych do Senatu Rządz. z 15 IX 1844 nr 4552, WMK V-102 B, k. 1239-1240 i 1245-1246. Pozostałe miały czekać na oszczędzających w Składzie druków rządowych.

${ }^{48}$ I. Homola, Wiktor Kopff, „Polski Słownik Biograficzny”, t. XIV/1, z. 60, Wrocław-Warszawa-Kraków 1968, s. 18-19. W. Kopff był m.in. sędzią Trybunału I Instancji oraz Sądu Apelacyjnego, następnie senatorem WMK, członkiem Komitetu Cenzury, komisarzem Towarzystwa Kolei Żelaznej, autorem publikacji naukowych oraz projektów ustaw (np. o lichwie, o dozorach kościelnych, cmentarzach, posiadłościach wieczystych).

${ }^{49}$ C. Bąk, Konstanty Hoszowski, „Polski Słownik Biograficzny”, t. X/1, z. 44, Wrocław-Warszawa-Kraków 1962, s. 31-32. W trakcie swojej kariery urzędniczej K. Hoszowski był zatrudniony m.in w Wydziale Spraw Wewnętrznych, Wydziale Dochodów Publicznych, pełnił też funkcje komisarza rządowego przy Kongregacji Kupieckiej.

${ }^{50}$ Pismo Senatu Rządz. do W. Kopffa, K. Hoszowskiego, L.Bochenka, J. Wolańskiego, L. Helcla, J. Czecha, K. Jędrzejowskiego, T. Witkowskiego z 20 IX 1844, WMK V-102 B, k. 1234-1237. Ich wynagrodzenie miał ustalić Senat, po półrocznym okresie działalności Kasy Oszczędności.

${ }^{51}$ Przewodniczącym (prezydującym) nadal był W. Kopff, przedstawicielem Arcybractwa mianowano radcę Franciszka Ciesielskiego. W 1847 r. w roli czynnika obywatelskiego pojawił się Aleksander Wąsowicz. Buchalterem-kontrolerem został Ludwik Mydlarski. Kalendarzyk polityczny krakowski na rok 1846, Kraków 1846, s. 36; Obwieszczenie Dyrekcji Kasy Oszczędności Miasta Krakowa z 22 I 1847 nr 2 DDKO, dodatek do „Dziennika Rządowego Miasta Krakowa i jego Okręgu" (dalej: Dz. Rząd. MK) z 1847 roku.

${ }^{52} \mathrm{Z}$ czego do końca 1844 r. miały miejsce 193 wpłaty, na 104 książeczki wpłynęło 5320 złp. W 1845 r. było 436 wpłat na 92 książeczki (9776 złp), w 1846 r. 234 wpłaty na 68 książeczek (9859 
w Jaworznie (razem 272) znalazło się 25463 złp, wliczając w to gwarantowane oprocentowanie (,ilość składki wniesionej, z obrachowanym procentem”); pieniądze wpłacano 887 razy (,ilość składek”), w tym 863 w Krakowie. W powyższym okresie wycofano (zwrócono) 122 książeczki, na kwotę 10914 złp 10 gr. wypłacając przy tym należne oprocentowanie. Podjęto też część funduszów z kont (,cząstkowo podniesiono”), na kwotę 2385 złp 15 gr. Ogółem wypłacono 13299 złp 25 gr. Na dzień 31 grudnia 1846 r. w Kasie Oszczędności pozostawało 12163 złp 5 gr. Po doliczeniu ,przypadającego od składek procentu" (494 złp 2 gr.) Kasa Oszczędności posiadała środki (będąc zarazem zobowiązaną) na kwotę 12657 złp 7 gr. ${ }^{53}$.

Warto przytoczyć też obliczenia dotyczące wielkości wpłat na konto Kasy Oszczędności. Z „Wykazu wniesionych i wypłaconych kwot” wynika, że najczęściej były to drobne kwoty. W powyższym okresie na 264 wpłaty w kasie krakowskiej, aż 81 stanowiły wpłaty w przedziale od 1-20 złp; 44 wpłaty od 21-50 złp, 59 wpłat od 51-100 złp ${ }^{54}$. Analogicznie kształtowała się sytuacja w kasie jaworznickiej: na osiem wpłat aż siedem sytuowało się w przedziale od 1-21 złp, a tylko dwie obejmowały kwotę bardziej okazałą (528 złp) $)^{55}$.

Kasa Oszczędności kontynuowała działalność mimo istotnych przemian organizacyjno-prawnych, wprowadzanych przez władze austriackie w następstwie inkorporacji Wolnego Miasta Krakowa do monarchii habsburskiej (16 XI 1846 r. $)^{56}$. W drugiej połowie 1847 r. w Wiedniu zapadła decyzja o ,ujednoliceniu zarządu państwowego" w byłej Rzeczypospolitej Krakowskiej. Skutkowała ona

złp). Łącznie w Kasie Oszczędności w Krakowie zdeponowano 24955 złp, w filii jaworznickiej zaś 508 złp. Z powyższych kwot elokowano: z wpływów w 1844 r. - 9200 złp; w 1845 r. - 5000 złp, w 1847 r. - 2000 złp, razem 16200 złp. Zob. „Czas” nr 70 z 25 III 1850.

${ }^{53}$ Obwieszczenie Dyrekcji Kasy Oszczędności Miasta Krakowa z 22 I 1847 nr 2 DDKO, Dodatek do Dz. Rząd. MK z 1847 roku. Wedle zapewnień Dyrekcji Kasy fundusze zostały lokowane na ,pewną hipotekę".

${ }^{54}$ Ponadto odnotowano 29 wpłat w przedziale od 101-150 złp, 18 od 151-200 złp, 5 od 201250 złp, 7 od 250-300 złp, 4 od 301-350 złp, dwie od 351-400 złp, a ponadto po jednej wpłacie w przedziałach: od 401-450 złp, od 451-500 złp, od 501-550 złp, od 701-750 złp, od 801-850 złp, od 951-1000 złp, od 1051-1100 złp. Obliczenia własne na podstawie: Wykaz wniesionych $i$ wpłaconych w Kassie Oszczędności Krakowskiej kwot od dnia 6 października 1844 r. do dnia 31 grudnia 1846 r., Dodatek do Dz. Rząd. MK z 1847 roku, s. 1-4.

55 Ibidem, s. 4.

${ }^{56}$ Było to rezultatem przegranego Powstania Krakowskiego. O przeobrażeniach w krakowskiej administracji zob. M. Mataniak, Rada Administracyjna Miasta Krakowa i Jego Okręgu. Z dziejów XIX-wiecznej administracji krakowskiej, „Studia z Dziejów Państwa i Prawa Polskiego”, t. XIV, Kraków-Lublin-Łódź 2011, s. 145-171. O Powstaniu Krakowskim zob. H. Żaliński, 18 lutego 3 marca 1846. Czternaście dni, które wstrząsnęty Krakowem [w:] idem, Kraj, emigracja, niepodległość. Studia i szkice, Kraków 2006, s. 148-163; M. Śliwa, Rok 1846 w Galicji i późniejsza rewolucja 1848 [w:] Rok 1846 w Galicji. Ludzie-wydarzenia-tradycje. Zbiór studiów pod redakcją Michała Śliwy, Kraków 1997, s. 7-20. 
likwidacją Rady Administracyjnej i powołaniem w jej miejsce Urzędu Cyrkularnego. Odpowiednie postanowienie cesarskie ogłosił Komisarz Nadworny hr. Maurycy Deym. Do niego miało należeć kierowanie „administracją polityczną” oraz sprawowanie ,zarządu policyjnego" "57. Urzędnicy Kasy Oszczędności wystąpili do Komisarza Nadwornego z pytaniem, czy znajduje się ona wśród instytucji przeznaczonych do likwidacji; a także, czy w razie jej utrzymania, będzie uważana za kasę rządową czy też miejską. Pismo Komisji Nadwornej wyjaśniało, że ostateczna decyzja może zapaść dopiero po ewentualnym utworzeniu w Krakowie Rady Miejskiej ${ }^{58}$. Tymczasowo Dyrekcja Kasy Oszczędności znalazła się pod zwierzchnictwem Komisarza Nadwornego ${ }^{59}$.

Tymczasem w 1848 r. zarząd Kasy Oszczędności opublikował kolejne sprawozdanie, rozciągnięte na $1847 \mathrm{r}$. W latach 1844-1847 w obu kasach założono 284 książeczki, na których w wyniku 991 składek znalazło się 29275 złp 14 gr. (na kasę krakowską przypadało 28657 złp 14 gr., na jaworznicką 618 złp). Po uwzględnieniu należnego oprocentowania (1 173 złp 12 gr.), składki objęły sumę 30448 złp 26 gr. W rzeczonym okresie wypłacono (wraz z doliczonym procentem) 14706 złp 13 gr. znajdujących się na 165 książeczkach. Zarazem podjęto z konta „składkę cząstkową” w wysokości 3518 złp 15 gr. Łącznie wypłacono więc 18224 złp 28 gr. Skutkiem tego, na dzień 31 XII 1847 r. w Kasie Oszczędności (wraz z filią w Jaworznie) pozostawało 12223 złp 28 gr. ${ }^{60}$.

Warto pochylić się również nad kolejnym raportem Dyrekcji Kasy, obejmującym dodatkowo lata 1848-1849. Wynika z niego, że w latach 1844-1849 w obu kasach na 297 książeczkach zdeponowano 32411 złp 6 gr. (w Krakowie 31793 złp 6 gr. w Jaworznie 618 złp.). Po dodaniu do tego oprocentowania (do 31 XII 1 849-2 024 złp 3 gr.) ogół składek ,z obliczonym procentem” wyniósł 34435 złp 9 gr. W powyższym okresie zwrócono 204 książeczki, na kwotę 18814 złp 10 gr.

57 Rozporządzanie Komisarza Nadwornego z 20 XII 1847, Dz. Rząd. MK nr 258-261 z 29 XII 1847, s. 1033-1038; Postanowienie cesarskie z 29 IX 1847; „Gazeta Krakowska” nr 294 z 24 XII 1847; J. Bieniarzówna, Z dziejów liberalnego i konspiracyjnego Krakowa (1833-1846), „Biblioteka Krakowska” nr 106, Kraków 1948, s. 123-124. Szefem Urzędu Cyrkularnego został starosta cyrkularny Wilhelm Krieg de Hochfelden.

${ }^{58}$ Pismo Komisji Nadwornej do Dyrekcji Kasy Oszczędności z 17 XII 1847 nr 3576 [za:] J. Miłkowski, op. cit, s. 8. Należy zaznaczyć, że jednym z kluczowych problemów była wypłacalność Kasy Oszczędności, którą musiały gwarantować władze miejskie bądź administracja rządowa.

59 Zob. Rozporządzanie Komisarza Nadwornego z 20 XII 1847, Dz. Rząd. MK nr 258-261 z 29 XII 1847, s. 1033 (art. 7, 8 pkt c). O przejściu Kasy Oszczędności pod zarząd państwowy zob. J. Demel, Stosunki gospodarcze i społeczne Krakowa w latach 1853-1866, „Biblioteka Krakowska” nr 112, Kraków 1958, s. 124.

${ }^{60}$ Wykaz wniesionych i wpłaconych w Kassie Oszczędności Krakowskiej kwot od dnia 6 października 1844 r. do dnia 31 grudnia 1847 r. z 31 I 1848, dodatek do Dz. Rząd. MK nr 47-48 z 25 II 1848. W 1847 r. wydano więc 12 książeczek, składki wnoszono 104 razy, wpłacono 3812 złp, aktywa Kasy (zysk) wyniosły 4985 złp. „Czas” nr 70 z 25 III 1850. 
(z uwzględnieniem doliczonego procentu); podjęto też część składek, na kwotę 5304 złp 7 gr. Razem wypłacono więc 24118 złp 17 gr. Na dzień 31 XII 1849 pozostawało w dyspozycji obu kas 10316 złp 22 gr. $^{61}$.

Na podstawie danych dziennikarza krakowskiego „Czasu” z marca 1850 r. powyższe informacje można uzupełnić o kolejne zestawienia. W 1848 r. miało miejsce 57 wpływów na 6 książeczek (1 934 złp), w 1849 r. 30 wpływów na 5 książeczek (1 $200 \mathrm{złp),} \mathrm{w} \mathrm{okresie} 1$ I - 21 III 18506 wpływów (215 złp). Łącznie w latach 1844-1850 miały miejsce 1064 wpływy na 287 książeczek, na kwotę 32000 złp 6 gr. Z wpływów w 1849 r. elokowano 2500 złp, razem dla okresu 18441849 było to więc 18700 złp. Ponieważ jednak od kwoty 18700 złp należało się 4305 złp, do 31 XII 1849 wpłynęło faktycznie 4030 złp. Po stronie dochodów Kasy Oszczędności można było również zaliczyć: zwrócony kapitał, lokowany na dobrach Pisary ( 2500 złp), wpływy z 205 książeczek od osób, które odebrały swoje kapitały (po 10 gr. od książeczki, co dawało 68 złp 10 gr.), ekstarordynaria, czyli zwrot za ogłoszenie w gazecie (14 złp 20 gr.), kapitał rezerwowy (fundusz żelazny) 6000 złp oraz wpływy kasy w Jaworznie, która przechowywała 9 książeczek (618 złp). Razem w okresie 11844 do 21 III 1850 było to $45240 \mathrm{złp}^{62}$.

Interesująco przedstawia się także zestawienie rozchodów Kasy Oszczędności. Na przykład w 1845 r. zwroty objęły 33 książeczki, w tym zwroty zupełne na kwotę 3559 złp, zwroty częściowe z oprocentowaniem na 56 złp 26 gr. Razem zwrócono 3615 złp 26 gr. $^{63}$.

W 1848 r. doszło do kolejnych zmian w administracji, spowodowanych wydarzeniami Wiosny Ludów. Pierwszym krokiem władz w Wiedniu było mianowanie (30 lipca 1848 r.) Wacława Zaleskiego gubernatorem Galicji, w miejsce Franciszka Stadiona $^{64}$. Następnie doszło do likwidacji (19 sierpnia 1848 r.) Komisji Nadwornej, której funkcje przejęła Komisja Rządowa, zwana później Komisją Gubernialną. Równocześnie administrację Okręgu Krakowskiego przejęła reaktywowana Rada Administracyjna; w Krakowie rządy miała sprawować Rada Miejska, wybrana przez obywateli miasta ${ }^{65}$. Wybory samorządowe doszły

${ }^{61}$ Wykaz wniesionych $i$ wpłaconych w Kassie Oszczędności Krakowskiej kwot od dnia 6 października 1844 r. do dnia 31 grudnia 1849 r. z 12 I 1850, dodatek do Dz. Rząd. MK nr 16-17 z 25 I 1850. Ponownie zapewniono, że środki „lokowano na pewną hipotekę”.

62 „Czas” nr 70 z 25 III 1850.

${ }^{63}$ W 1846 r. 89 książeczek, zwrot zupełny 7134 złp 10 gr., zwrot zoprocentowaniem 145 złp 20 gr. (razem 7300 złp); w 1847 r. 44 książeczki, zupełny 3518 złp 19 gr., z oprocentowaniem 157 złp 4 gr. (razem 3703 złp 22 gr.); w 1848 r. 30 książeczek, zupełny 2874 złp 20 gr., z oprocentowaniem 315 złp 24 gr. (razem 3190 złp 14 gr.); w 1849 r. 9 książeczek, 977 złp 13 gr. z oprocentowaniem 24 złp 9 gr. (razem 1001 złp 22 gr.). „Czas” nr 70 z 25 III 1850.

${ }^{64}$ Obwieszczenie Komisarza Nadwornego z 4 VIII 1848 nr 2587, Dz. Rząd. MK z 12 VIII 1848 nr 145-146, s. 579. Komisarzem Nadwornym został Franciszek Schlick.

${ }^{65}$ Zob. Dz. Rząd. MK nr 150-152 z 25 VIII 1848, s. 597-598; J. Bieniarzówna, J.M. Małecki, Dzieje Krakowa, t. 3: Kraków w latach 1796-1918, Kraków 1979, s. 192; A. Chmiel, Ustrój Kra- 
do skutku 25 września 1848 r. Rada Miejska rozpoczęła działalność 6 października 1848 r. ${ }^{66}$.

W październiku 1848 r. gubernator Zaleski wezwał Radę Miejską do przedstawienie opinii odnośnie dalszej działalności Kasy Oszczędności. Zwracał uwagę, że w pozostałych krajach koronnych cesarstwa podobne instytucje nigdy nie funkcjonowały w oparciu o gwarancje rządowe, w związku z czym zasadne byłoby dostosowanie kasy krakowskiej do zasad funkcjonowania Kasy Oszczędności we Lwowie ${ }^{67}$. Władze miasta wezwały więc Kasę Poborową, prowadzącą rachunkowość Kasy Oszczędności, aby przedstawiła aktualny stan finansów oraz wskazała przyczyny niewielkiego zainteresowania ideą oszczędzania wśród Krakowian. W opinii Kasy Poborowej, podstawowym czynnikiem utrudniającym rozwój Kasy Oszczędności było korzystanie z jej usług przez przedstawicieli klas zamożniejszych, a nie ludzi uboższych. Powodem była zbyt niska stopa procentowa, a zwłaszcza ogólne zubożenie społeczeństwa i „niemożność zaoszczędzenia czegokolwiek"; powyższa opinia została przedstawiona Gubernatorowi we wrześniu 1849 r. Kasa Poborowa stwierdziła też zasadniczą zgodność statutu Kasy Oszczędności w Krakowie z regulaminem kasy lwowskiej, przy czym austriacka propozycja podwyższenia minimalnej wpłaty (z 1 złp do $25 \mathrm{kr}$.) mogła jedynie pogorszyć sytuację ${ }^{68}$.

Można dodać, że postulat zachowania Kasy Oszczędności pojawił się w wystąpieniu deputacji krakowskiej (Maurycy Potocki, Antoni Zygmunt Helcel, Stefan Potocki, Jacenty Rzesiński) z kwietnia 1848 r. do cesarza Ferdynanda I ${ }^{69}$.

Kasą Oszczędności interesował się także nowy gubernator Agenor Gołuchowski, który w 1850 r. wskazywał Radzie Miejskiej postanowienia jej statutu, które w żadnym razie nie mogły być utrzymane. Najistotniejsze było zwolnienie rządu z udzielania rękojmi wypłacalności Kasy. Gołuchowski proponował też, że postara się wyjednać w Wiedniu zgodę na utworzenie w Krakowie filii Galicyjskiej Kasy Oszczędności we Lwowie. Jeden z krakowskich radnych optował z kolei za

kowa lat 1790- 1866, cz. IV: 4 marca 1846- 30 czerwca 1853, ANK, „Spuścizna Adama Chmiela”, sygn. ACh 39, k. 319.

${ }^{66}$ A. Chmiel, Ustrój Krakowa w XIX wieku [w:] Kraków w XIX w., t. II, „Biblioteka Krakowska” nr 72, Kraków 1932, s. 103-104; J. Demel, Stosunki gospodarcze i spoteczne Krakowa w latach 1846-1853, s. 20-21; Obwieszczenie Gubernatora Galicji z 17 X 1848 nr 168 KP, Dz. Rząd. MK nr 180-183 z 18 X 1848, s. 731-732.

${ }^{67}$ Pismo Gubernatora Galicji do Rady Miejskiej z 21 X 1848 nr 181 KP [za:] J. Miłkowski, op.cit., s. 9. Gubernator przesłał do wglądu regulamin kasy lwowskiej z 31 X 1844 nr 66931.

${ }^{68}$ Pismo Rady Miejskiej do Gubernatora Galicji z 19 IX 1849 nr 2794 [za:] J. Miłkowski, op. cit., s. 10.

${ }^{69}$ K. Ostaszewski-Barański, Wacław Michat Zaleski (1799-1849). Zarys biograficzny, Lwów 1912, s.144-145; dodatek do nr 50 ,Jutrzenki” z 27 V 1848 (Odpowiedź Deputacji z 18 V 1848 r.). Domagano się m.in. także rozdzielenia majątku gminnego (miejskiego) i państwowego. 
wprowadzeniem, przy okazji układania nowego statutu dla kasy krakowskiej, rozwiązań węgierskich, obowiązujących w Koszycach i Preszowie. Wniosek został jednomyślnie przyjęty, Rada Miejska wydelegowała nawet czterech radnych oraz trzech członków Izby Przemysłowo-Handlowej do komisji, która miała opracować projekt wzorowany na statucie obowiązującym w Koszycach ${ }^{70}$.

Ostatecznie ambitnych planów władz miejskich nie udało się wcielić w życie. Opracowany projekt statutu nie uzyskał aprobaty, m.in. wskutek nieprzedłożenia wykazów majątku gminnego, przy pomocy którego miano ręczyć za wypłacalność Kasy wobec deponentów. Opracowanie takiego wykazu uniemożliwiało natomiast niedojście do skutku oddzielenia majątku gminnego od państwowego. Nie udało się również przeforsować koncepcji włączenia Kasy Oszczędności do kasy we Lwowie, która osiągała wówczas bardzo dobre wyniki finansowe (np. w 1853 r. odnotowała $3 \mathrm{mln}$ złotych reńskich wkładów ${ }^{71}$. Wkłady kasy krakowskiej były zaś bardzo nieliczne, w wyniku czego dysponowała ona niewielkim kapitałem. Jeszcze w 1852 r. władze miejskie próbowały nawiązać współpracę z Arcybractwem Miłosierdzia, co miało pomóc w uratowaniu Kasy Oszczędności. Ponieważ względy formalne (statut Arcybractwa) nie pozwalały na połączenie Banku Pobożnego z kasą miejską, Rada Miejska zwróciła się do niego o ponowne wyasygnowanie $6000 \mathrm{złp}$. Ostatecznie, w 1857 r. doszło do likwidacji Kasy Oszczędności. Zdaniem J. Demela był to dotkliwy cios dla mieszkańców Krakowa, powodujący zwiększenie różnic ekonomicznych między Krakowem i Galicją oraz pozostałymi prowincjami monarchii habsburskiej. Nic więc dziwnego, że od 1858 r. zaczęły się pojawiać głosy domagające się przywrócenia Kasy Oszczędności ${ }^{72}$.

Dość krytyczną ocenę działalności Kasy Oszczędności wystawił Miłkowski, który jej byt określił jako „mdły i monotonny, mimo najlepszych chęci twórców”. Słusznie dostrzegł, że główną tego przyczyną był fakt, że mieszkańcy dysponowali zbyt małym kapitałem, mieli trudności w odłożeniu środków pieniężnych, jak również fakt, że funkcjonowanie kasy było zbyt mało propagowane przez władze Krakowa. Decydujący okazał się ogólny upadek handlu i przemysłu po $1846 \mathrm{r}^{73}$. Kasa Oszczędności rozporządzała skromnymi kapitałami. Roczne wpłaty nie przewyższały 10000 złp. W 1845 r. było to 9776 złp, w 1846 r. 9859 złp,

${ }^{70}$ J. Miłkowski, op. cit., s. 10-11. Aby zachęcić mieszkańców Krakowa do oszczędzania, a także dać dobry przykład, Rada Miejska planowała w związku z tym wyemitowanie 200 akcji; gubernator Gołuchowski stwierdził, że „Rząd od wszelkiej rękojmi za majątek Kassy powinien być wolen”.

${ }^{71} \mathrm{~W} 1851 \mathrm{r}$. były to wkłady na kwotę $1850000 \mathrm{złr}$, w 1852 r. ponad $2000000 \mathrm{złr}$, w $1853 \mathrm{r}$. 2500000 złr. J. Demel, Stosunki gospodarcze i społeczne Krakowa w latach 1846-1853, s. 189-190.

72 J. Demel, Stosunki gospodarcze i społeczne Krakowa w latach 1853-1866, s. 124-125. Kilkanaście kas oszczędności funkcjonowało także w Królestwie Polskim.

73 J. Miłkowski, op. cit., s. 8. O sytuacji w Krakowie zob. J. Purchla, Kraków u progu autonomii galicyjskiej, „Rocznik Krakowski”, t. LVI, 1990, s. 170-171; W. Wielogłowski, Kraków jako główne targowisko zbożowe i punkt handlowo-przemystowy, Kraków 1860, s. 17. 
w 1848 r. 1934 złp, w 1849 r. 1200 złp. Od 1847 r. suma wypłat przewyższała wpłaty (w 1847 wpłacono 3792 złp, wypłacono 4681 złp; w 1848 r. odpowiednio 1934 i 3369 złp; w 1849 r. 1200 i 2268 złp). Spadała też liczba członków: w 1845 r. były to 163 osoby, w 1846 r. 142 , w 1849 r. zaledwie $86^{74}$.

\section{CREATION OF THE SAVINGS BANK IN THE FREE CITY OF CRACOW AND ITS ACTIVITY BETWEEN 1844 AND 1857}

\section{Summary}

The article presents the activity of the Savings Bank in Cracow between 1844 and 1857. It recreates the course of works undertaken during its creation by the Representatives Assembly. The basic ideological assumptions on which it was based were shown. Moreover, the paper presents the participation in the creation process of the Brotherhood of Mercy and of the Mount of Piety (Latin Mons Pietatis). The legal basis of the Savings Bank's functioning was analyzed in detail. The foundation had the shape of statutory law from the 3rd of July 1844, the organization of the Management of the Savings Bank, the rules of depositing and withdrawing the savings, keeping accountancy and its control by the authorities. Also detailed data was included pertaining to the size of the deposit and the size of the withdrawal made from the Savings Bank. The basis of the article consists of the archival materials from the National Archive in Cracow and of the announcements made by the Management of the Savings Bank, which were published in "The Governmental Gazette".

\section{CRÉATION DE LA CAISSE D’ÉPARGNE DANS LA VILLE LIBRE DE CRACOVIE ET SON ACTIVITÉ DANS LES ANNÉES 1844-1857}

\section{Résumé}

L'article présente l'activité de la Caisse d'épargne de Cracovie, dans les années 18441857. Nous avons retracé les travaux liés à sa création menés par l'Assemblée des Représentants, en montrant les hypothèses de base sur lesquelles elle était fondée, y compris la participation de l'Archiconfrérie de la Charité et de la Banque Pieuse. Nous avons aussi analysé en détail la Loi du 3 juillet 1844, y compris l'organisation de la Direction de la Caisse d'épargne, les règles de collecte et de paiement de l'épargne, la comptabilité et le contrôle par les autorités gouvernementales. Les informations détaillées sur les montants des versements à la Caisse d'épargne et des retraits de l'argent sont également fournies. Aux fins de cet article, on s'est servi comme principale source de données des actes recueillis dans les collections des Archives nationales de Cracovie ainsi que des annonces de la Direction de la Caisses d'épargne parues dans le journal: «Dziennik Rządowy» [«Journal du gouvernement»].

74 J. Demel, Stosunki gospodarcze i społeczne Krakowa w latach 1846-1853, s. 189; „Czas” nr 70 z 25 III 1850. 
